\title{
Preservice Teacher Leaders Learn to Advocate Legislatively Through Professional Organizations
}

\author{
Nathan Bond ${ }^{1, *}$ \\ ${ }^{1}$ Department of Curriculum and Instruction, Texas State University, San Marcos, Texas, USA \\ *Correspondence: Department of Curriculum and Instruction, Texas State University, San Marcos, Texas, USA. \\ E-mail: NathanBond@txstate.edu
}

Received: July 25, 2016

Accepted: August 10, 2016 Online Published: September 1, 2016

doi:10.5430/jct.v5n2p25

URL: http://dx.doi.org/10.5430/jct.v5n2p25

\begin{abstract}
Teachers often do not interact with legislators when educational policy is being developed. As a way to facilitate more interaction between the two groups, scholars are calling for teacher leaders to step forward and participate in legislative advocacy. The invitation is not limited to in-service teacher leaders. Preservice teacher leaders can participate in policymaking if they are taught about legislative advocacy during their preparation programs. This qualitative case study describes what happened when three preservice teacher leaders learned how to advocate for the education profession by attending three workshops hosted by a student professional organization. The data show that the preservice teachers began the experience with a desire to have a voice in developing policy. Through the workshops they learned about the legislative process, ways to advocate through writing and in person, and the role of legislative aides. The findings indicate that student professional organizations are a viable way for teacher preparation programs to help aspiring teacher leaders learn about legislative advocacy and make their voices known to policymakers.
\end{abstract}

Keywords: legislative advocacy; teacher leadership; professional organizations; teacher preparation programs

\section{Introduction}

Education in the United States has come under intense scrutiny during the last several decades as parents and politicians have demanded greater accountability for student learning. Although these well-intentioned stakeholders are actively involved in creating and implementing policy, some of them, according to critics, lack in-depth backgrounds in education and mistakenly think that having attended school or having children in school makes them experts in the field (Dever, 2006). A subset of these stakeholders act with questionable motives and appear more interested in winning elections than in creating a good future for children (Palmer, 2008).

What exacerbates the situation is the role, or the lack thereof, that teachers play. Teachers have been "an underutilized voice on how to improve schools" (Flom, 2010, para. 5). Policymakers have not sought out teachers' perspectives, and teachers have simultaneously remained silent, thereby abdicating their professional and ethical responsibilities (Galer-Unti, Tappe, \& Lachenmayr, 2004). In short, "Educators have largely ceded the public debate about education to others" (Cohen, 2008, p. 1).

In response to this situation, scholars are calling for classroom teachers to step forward, lead beyond their classrooms, and advocate for education (Eckert, Ulmer, Khachatryan, \& Ledesma, 2015; York-Barr \& Duke, 2004). Teacher leaders are being asked to set aside their adversarial stances toward policymakers and strive for a mutual understanding of each other's complex perspectives and responsibilities (Kajitani, 2015). Working with politicians to create policy characterizes the fourth wave of teacher leadership. Since its inception, the field of teacher leadership has passed through four stages in its evolutionary development. In the first three waves, teacher leaders served in formal managerial roles, focused on improving instructional practices, and collaborated to re-culture schools (Silva, Gimbert, \& Nolan, 2000). In this fourth wave, teacher leaders do not simply react to policy but proactively drive policies that solve problems in schools. 
The call for teachers to lead is not limited to experienced teachers; beginners can lead, too (Pucella, 2014). Although novices can lead, they usually are not trained to lead. Snyder (2015) posits that an ideal time to teach them about teacher leadership is during their preparation programs. He states:

A program cannot expect graduates to accomplish what they have not been introduced to in their preparation. Unless candidates have opportunities to learn, practice, and assess their development in understanding how teaching and leadership are inextricably intertwined, they may be less likely to do either of them well (pp. 10-11).

To recap, teacher leaders at all levels, including those completing their preparation programs, need to take an active role in working with decision makers to develop sound educational policy. The participants in this qualitative case study responded to the call to lead and took the first steps in learning about legislative advocacy and educational policy. This study describes their efforts to address the following research question: What happens when three preservice teacher leaders learn through a professional organization how to advocate legislatively for children at the state level?

Legislative advocacy differs from other types of advocacy. Robinson and Stark (2005) outline the three types: public, personal, and private-sector. Public, also known as legislative advocacy, involves working with elected officials to develop policy. Personal advocacy concentrates on educating people with whom one has personal contact, such as students, parents, teachers, administrators, and community members, about an issue. The third type, private-sector advocacy, focuses on informing and involving business people about education-related matters. The study described in this paper focuses on public or legislative advocacy.

\subsection{Theoretical Framework}

The study draws upon the developmental theory of teacher leadership proposed by Lambert (2003). Using a continuum as a model, she purports that novices first learn how to lead by participating in small, structured, and supported ways; and then they progress incrementally over time to take on larger, more complex roles. Operationalizing the theory, Bond (2011) urges teacher preparation programs to "introduce the concept of teacher leadership in their courses and provide these novices with a mental framework for approaching teacher-related tasks and opportunities to develop as teacher leaders" (p. 294). Teacher educators should equip preservice teachers with the knowledge, skills, and dispositions of leaders and allow them, under the tutelage of experienced mentors, to practice what they learn.

\subsection{Relevant Scholarship}

This study brings together four lines of scholarship: legislative advocacy, teacher leadership, student professional organizations, and teacher preparation. A review of the literature uncovered no research encompassing all four lines; however, the search found studies that merge at least two of the areas. These include teacher leadership and teacher preparation, advocacy and teacher preparation, advocacy and teacher leadership, and advocacy and professional organizations. These combinations are reviewed below.

\subsubsection{Teacher Leadership and Teacher Preparation}

The literature discusses ways for preservice teachers to learn about teacher leadership during their teacher preparation programs. A common way is for them to interact with more experienced teacher leaders. Dunlap and Hansen-Thomas (2011) describe a project in which they, as professors and researchers, worked with several preservice teacher leaders to prepare them to give a panel presentation at a professional conference. By going through the steps to prepare and give the presentation, the novices learned the value of collaboration, risk-taking, and the sharing of instructional expertise with others. The study found that "creating this presentation gave the preservice teachers the chance to learn leadership skills that, in turn, gave them the confidence, tools, and encouragement to serve as teacher leaders" (p. 21).

In a related study, Shillingstad, McGlamery, Davis, and Gilles (2015) discuss how experienced teachers mentored preservice teachers who were preparing to assume their first teaching positions. The mentors modeled leadership and encouraged the novices to consider teacher leadership roles. As a result of the side-by-side approach to mentoring, the novice teachers were able to "practice and develop expertise under the guidance of a more knowledgeable peer" (p. 15).

If preservice teachers are unable to have direct interactions with teacher leaders, they can pursue virtual opportunities. Working at separate institutions, Holland, Eckert, and Allen (2014) asked their preservice teachers to read articles about teacher leadership and then interact via video conferencing with teacher leaders across the country. The researchers found that the virtual interactions were just as successful as in-person interactions, the preservice 
teachers were well-informed on the realities of schools, and the ties between teacher educators and practitioners were strengthened.

Although the approaches above are limited in scope, others go further in depth and describe teacher educators developing entire courses on teacher leadership. Crippen (2010) organized a teacher licensure course around the idea of servant leadership. As part of the course curriculum, preservice teachers learned about Greenleaf's (1977) characteristics of servant leadership. The study determined that the semester-long course helped the preservice teacher leaders to understand the importance of balancing their positional power as educators with the moral responsibility of serving or supporting others.

Following a similar approach, Diana (2011) used action research projects in his course to help preservice teachers become teacher leaders. By adhering to the steps for implementing an action research project, the novice teacher leaders developed the analytical skills necessary for leadership. Specifically, they learned how to identify a problem, collect and analyze data, and develop an action plan. The action research project met the goal of providing "preservice teachers with meaningful professional development opportunities so that they can become effective teacher leaders" (p. 170).

\subsubsection{Advocacy and Teacher Preparation}

Teacher educators can engage preservice teachers in issues related to students by employing advocacy as a pedagogical approach. The steps of the approach require preservice teachers to choose an issue that affects their students, research it, identify decision makers who can bring about change, and then develop an action plan that seeks to remedy the situation. In a study that examines advocacy as pedagogy, Dever (2006) first shared her own experiences as an advocate for young children with her preservice teachers and then worked with them to "design and implement authentic projects as a class assignment" (p. 394). The preservice teachers responded positively to the project because they simultaneously learned about their students and the issues affecting them and also learned some advocacy strategies for addressing the issues.

Employing a similar approach, Wade (2003) noticed that preservice teachers in her social studies methods course understood the dire situation of some students yet took no active steps to "try and affect change in regard to laws, policies, and societal practices that create inequity" (p. 129). In response, she developed an advocacy project that would help preservice teachers to realize the importance of civic engagement. The results show that the preservice teachers liked the project and vowed to continue participating in advocacy after graduation from the university.

A third study by Beacham and Shambaugh (2007) found similar results. These researchers created an advocacy assignment that utilized a problem-based learning (PBL) teaching strategy. They concluded that the PBL and the advocacy approach deepened preservice teachers' thinking about the issues and motivated them to take action.

Rather than completing a PBL, Massengale, Childers-McKee, and Benavides (2014) engaged their preservice teachers in a letter-writing campaign to decision makers about personally meaningful issues. Again, the results showed that advocacy is an effective pedagogical approach that helps preservice teachers to understand their students, issues affecting their students, and the steps for remedying the issues.

\subsubsection{Advocacy and Teacher Leadership}

Advocating for the profession is one of the seven Teacher Leader Model Standards, which outline what teacher leaders should know and be able to do (Teacher Leadership Model Standards, 2011). Domain 7 states that "the teacher leader understands the landscape of education policy and can identify key players at the local, state, and national levels. The teacher leader advocates for the teaching profession and for policies that benefit student learning" (para. 1). The writers of the standards explain how teacher leaders can advocate for the profession. To name a few of these methods, they can share advocacy-related information with colleagues, use research to advocate for students and teachers, and disseminate information beyond the school.

Teacher leaders are ideal people to serve as advocates because they possess authority of expertise and moral authority (Hess, 2015). Teachers' authority of expertise comes from their ongoing work in schools and their unique perspectives; they know better than anyone the effects of policies and decisions on students and classrooms. Teachers earn their moral authority by consistently striving for professional excellence and convincing parents and policymakers that educators are the guardians of the public's interests (Hess, 2015). As Palmer (2008) explains, "Today's professionals have an ethical obligation to help transform the toxic settings in which their work is done" (p. 12). In other words, he claims that teachers must lead with their souls. 


\subsubsection{Advocacy and Professional Organizations}

Teacher leaders can advocate by participating in professional organizations (Lieberman, 2014). These groups serve an educational function by informing teachers about the policies that affect their jobs (Hammett, 2006) and by helping them to develop strategies for speaking to decision makers at the local, state, national, and international levels (Elpus, 2007; Galer-Unti, Tappe, \& Lachenmayr, 2004). Still another benefit of membership in professional organizations is the connection between teachers and the larger community of like-minded individuals who are interested in similar educational issues.

There are professional organizations designed specifically to help teachers become teacher leaders and advocates. For example, Teach Plus is a national organization whose mission is to "empower excellent, experienced teachers to take leadership over key policy and practice issues that affect their students' success" (Teach Plus, 2015, para. 1). To accomplish this goal, the organization "recruits, selects, and trains outstanding teachers to be leaders in their schools and in district and state policy debates" (Coggins \& McGovern, 2014, p. 16). The programs organized by Teach Plus give teacher leaders venues for "direct engagement with policy makers, congressional testimony, media placements, and public forums for voicing their opinions" (Coggins \& McGovern, 2014, p. 16). Other groups, such as Educators 4 Excellence and the Hope Street Group, provide fellowships for teachers who remain in the classroom to learn about and influence educational policy (Eckert, Ulmer, Khachatryan, \& Ledesma, 2015). Some professional organizations, such as the National Education Association, the Center for Teaching Quality, and the National Board for Professional Teaching Standards, partner with other organizations to develop professional development courses in which teachers study leadership and education policy (Yaffe, 2014).

In-service teachers are not the only ones who can learn about advocacy through membership in professional organizations. Preservice teachers can join clubs or student professional organizations while completing their university degrees. Membership connects them with others interested in policy and gives them opportunities to participate in outreach events where they can practice their advocacy skills (Radius, Galer-Unti, \& Tappe, 2009). Furthermore, preservice teachers can attend conferences hosted by the professional organizations where they have access to advocacy-focused sessions and networking events with other advocates (Richards, Aros, \& Ostrander, 2015).

\section{Method}

The researcher/author of this manuscript received approval from his university's review board and the participants to conduct this qualitative, descriptive case study. He chose case study methodology because his research approach was "to understand complex social phenomena" (Yin, 2014, p. 4). The study examined three undergraduate preservice teachers seeking licensure in elementary education. These participants were also serving as student officers of a local chapter of a professional organization in education. A case in this study was defined as one preservice teacher.

\subsection{Researcher's Positionality}

The author assumed two roles in this study. First, he was the faculty sponsor of the professional organization, a role he has fulfilled for the past 16 years. One of his goals as the sponsor is to help the student officers develop their leadership skills, with the hope that they will begin viewing themselves as teacher leaders and carry this perspective with them when they begin their first teaching positions. Second, he was the researcher who designed and conducted the study and who wrote this manuscript. Throughout the study he had to balance the role of the faculty sponsor who supported his students with the role of the objective researcher.

\subsection{Setting}

The study occurred at a large public university located in the southwestern United States. The education department, known nationally for its long history of teacher preparation, certifies approximately 500 new teachers each semester. The department is also home to five active collegiate chapters of professional organizations in education.

The study participants belonged to Kappa Delta Pi, International Honor Society in Education (KDP), an honorary and professional organization that was established in 1911 by Dr. William Bagley at the University of Illinois at Urbana-Champaign. KDP's membership is comprised of approximately 30,000 educators at all stages of their careers. Staff members at the organization's national headquarters in Indianapolis, Indiana, work with the faculty sponsors, student officers, and members in the collegiate and professional chapters to complete three basic functions: recognize new members during initiation ceremonies, host professional development opportunities for students in their teacher preparation programs, and complete service projects in the local community. The workshops described in this study were intended to provide professional development to the participants. 


\subsection{Participants}

The three student participants had both similar and different traits. All were females who were in the second semester of a four-semester teacher preparation program at the undergraduate level. All aspired to become elementary school teachers, and all were serving as student officers of KDP. Two participants were White; one, African-American. Two were in their early twenties; one, late twenties. Two had little work experience in schools; one had worked as an administrative assistant in a school for two years before returning to the university to earn a degree. Table 1 provides an overview of the participants. All names are pseudonyms.

Table 1. Study Participants by Race, Age, and Work Experience in Schools

\begin{tabular}{llll}
\hline Participant & Race & Age & Experience in Schools \\
\hline Jane & African-American & early 20s & 0 years \\
Carol & White & early 20s & 0 years \\
Lisa & White & late 20s & 2 years \\
\hline
\end{tabular}

The study primarily focused on the three student participants; however, the professor who co-taught the three workshops with the researcher was included as a data source. The researcher conducted an interview with her to determine her perspective. Dr. Smith, a pseudonym, was a White woman in her 50s. For more than 12 years, she has worked as a teacher educator in the Department of Curriculum and Instruction at the university where the study occurred. Earlier in her career she taught social studies in a local public high school. Throughout her career she has been actively involved in her state and national professional organizations in social studies. Advocacy is one of her primary interests.

\subsection{Timeline of Events}

During the spring semester, the researcher/faculty sponsor of KDP asked the faculty participant if she would be willing to co-present three professional development workshops focused on legislative advocacy. The colleague was purposely chosen because of her extensive experience as an advocate for her professional organizations. The researcher also had expertise in advocacy. Earlier in his career he served as the advocacy director for his state-level professional organization in world languages, and he currently serves on the KDP Public Policy Committee. The faculty participant and the author developed the curriculum for the workshops and then invited all KDP chapter members to participate. Five students attended. Of the five, three were chapter officers, and these three agreed to participate in the study.

The first hour-long workshop provided an overview of the legislative process and advocacy. The interactive workshop addressed these questions: What is legislative advocacy? What are the steps of the legislative process in our state? How does a bill become law? How can citizens track a bill online? During the workshop the participants listened to the presenters share personal stories about advocacy, used their smartphones to locate bills on the state government's website, and asked specific questions they had about the legislative process. For homework, the participants were asked to conduct an Internet search, identify their state representative and state senator, and review these legislators' websites, paying particular attention to their positions on education.

A month later, the participants attended the second hour-long workshop. The interactive workshop addressed these questions: What is a current education-related bill that is moving through the state legislature? How can teachers advocate by writing letters, posting messages on social media, and meeting in person with legislators? How can membership in a professional organization assist in advocacy? During the workshop the participants role-played mock advocacy situations and examined actual letters that teachers had sent legislators.

For the third workshop, the participants traveled with the two workshop presenters to their state capitol where they toured the facility and located their legislators' offices. The participants met a legislative aide of the state representative who represents one of the workshop presenters. The aide welcomed the participants to the office, responded to their questions about pending bills, and recommended ways to advocate effectively.

\subsection{Data Collection}

Data came from three sources in this study: the curriculum of the three workshops, a one-hour online interview with the faculty co-presenter, and a one-hour in-person interview with each participant. These data allowed the researcher to examine the learning process. In short, he was able to study what was planned, what was taught, and what was learned. 
The curricular materials included the PowerPoint presentations, the handouts distributed during the workshops, and the state legislature's official website. These artifacts contained the information that was intended to be taught, such as the legislative process, legislators' views about education, and strategies for advocating in person and in writing via letters and social media.

At the conclusion of the workshop series, the researcher conducted a one-hour online interview with the co-presenter to analyze her intention in developing the curriculum for the workshops. The purpose of the semi-structured interview was to explore why she offered the workshops, what she hoped the participants would learn from the workshops, and why she delivered the workshops in the way that she did. It should be noted that she and the researcher co-developed and co-taught the workshops.

The researcher conducted one-hour in-person interviews with each participant. The purpose of the semi-structured interviews was to determine what the participants learned and to probe more deeply into their understanding of advocacy. The questions explored each participant's motivations for attending the workshops, prior knowledge about advocacy, and significant learnings from the experience. The researcher audio-recorded all interviews and transcribed them verbatim himself.

\subsection{Data Analysis}

The researcher followed an inductive approach to analyze the data. He started by reading and re-reading the data until patterns emerged naturally (Yin, 2014). He kept an open attitude toward the data because he was not trying to prove any preconceived hypothesis. He wanted to draw conclusions based on the curricular materials and the interviews. He followed this approach because there were few published studies that examined preservice teacher leadership, legislative advocacy, teacher preparation, and professional organizations.

During his initial reading of the data the researcher developed a global view of the information and identified topics using open coding (McMillan, 2016). As part of the process, he analyzed individual sentences in the curricular materials and interview transcripts, labeled each topic with a code, and created memos to document his beginning interpretations (Corbin \& Strauss, 2008) and to guide the development of a working hypothesis (Bogdan \& Biklen, 2007). To organize his findings, he merged specific codes to produce broader themes. The researcher repeated these steps until saturation occurred and no new ideas emerged from the data (Bogdan \& Biklen, 2007). He read the data one last time to verify his themes and excerpt key passages from the participants to use in the manuscript. To enhance the veracity or trustworthiness of the findings, the researcher triangulated the data, meaning that he only included themes that appeared in all three data sources. He also conducted member checks with each participant.

\section{Results}

This qualitative case study examined what happened when three preservice teacher leaders learned how to advocate legislatively for education at the state level through a professional organization. Emerging from the data were five themes: the participants' reasons for attending the workshops, their levels of background knowledge, the legislative process, the importance of an advocate's message, and the role of legislative aides. Each theme is elaborated below.

\subsection{Rationale for Advocacy}

The first theme focused on the reasons for attending the advocacy workshops. Dr. Smith stated, "The purpose was to engage preservice teachers in the conversation about education. They need to figure out how they can have their voices heard in the larger discussion about education and why professional engagement is important." To help the participants understand the reasons, the presenters spent time at the beginning of the first workshop defining advocacy, discussing its importance, and distinguishing it from lobbying.

After the workshops concluded, the participants acknowledged the impact of decision makers at local, state, and federal levels on teachers. Lisa stated, "I really wanted to understand how the state and federal decisions affect my work as a teacher." She continued, "You really need to know and understand the legislative process well in order to have a voice as a teacher and to know your information well when talking to a state legislator." Jane believed that advocacy was a characteristic of effective teaching. She explained:

We teachers are the ones who are affected the most out of this whole process. These bills basically dictate how we run our classrooms and assess our students. Legislators have the most impact on us teachers and our students. If you really want to be a good teacher, an effective teacher, then you need to know what's going on and what the laws are. And what's going on outside your classroom finds its way inside your classroom. You need to know what's going on in politics. 
Carol viewed teachers as the experts in education who are ethically bound to speak up. She noted:

If you're a teacher, you have to advocate. You can't just be involved in your classroom and not take it further. I think teachers should be more involved in the community and more involved with reaching out beyond their classrooms and trying to make a change on what they think is right. We are the experts on education. If we don't, then others are going to run schools as they see fit. If we don't say something, then they won't run schools the way that we think.

\subsection{Participants' Background Knowledge}

The participants' level of background knowledge was a second theme. Dr. Smith stated that the workshops were intended to be educational. She stated, "Preservice teachers may not be aware of advocacy. They may not be aware of how to think about it and how to do it." To help the participants learn about advocacy and the legislative process, the presenters pre-assessed orally the participants' background knowledge, showed them a short video about the legislative process, and gave them a diagram detailing the specific steps of the legislative process.

All participants recalled having taken the required government courses in high school and college and having learned the basic steps of the legislative process; however, they did not remember exactly how bills become laws. When initially describing the legislative process they used terms such as intimidating, confusing, overwhelming, complicated, and complex. The participants commented that these feelings had prevented them from being involved previously in advocacy efforts.

Furthermore, the participants had misconceptions about advocacy and the legislative process. Lisa stated that before the workshops she had little knowledge about advocacy, although she understood that "there were people out there who advocated for school districts." She did not realize that teachers could advocate. Carol had a little more knowledge, but she did not know about the legislative aides' roles and responsibilities. She commented:

I didn't know what was actually going on. I thought that it was just the legislators making all the decisions. I didn't realize that they have people in their offices who keep track of people's opinions. Their job is to take the information that you give them.

\subsection{Legislative Process}

During the first workshop the participants learned the steps of the legislative process. Dr. Smith explained, "In our state, it's important to recognize that anything dealing with school policy starts with the Legislature. Our elected officials ultimately dictate the laws, which they send to the state's education agency and eventually to the school districts." To help the participants understand the legislative process, the presenters introduced them to the Legislature's website where bills are tracked through various stages of development.

The participants were amazed at the number of filed bills. Jane exclaimed:

I learned that there are thousands of bills that try to get passed. Before the workshop I really didn't know a number. I guess I thought there were a lot, but I didn't know the true number. And when Dr. Smith talked about it, I was just mind-blown that there were so many.

Even though many bills are filed, few become law. Jane continued, "There are millions of them in the beginning, but in the end, only a few get passed into law. Getting one passed requires hard work." Lisa remarked that "there's no guarantee that the bill will become law."

Tracking a bill online and monitoring its journey through the legislative process were two new ideas that the participants learned during the first workshop. Jane stated, "I track bills more now that I know how to find them on the website. I have become really addicted to it! Now, I'm trying to look for ones with keywords and where they are in the process."

Furthermore, the participants realized that advocates have an opportunity to share their opinions and ultimately influence the bill. Carol explained:

During the process we have a chance to intersect the bill and put our input into it — where to say we support it or don't - that was really interesting to me. There's so much back and forth. If there's a bill that you want to follow, there are many opportunities for you to make your voice heard about it.

\subsection{Advocacy Message}

During the second workshop the participants learned ways to craft written and in-person advocacy messages. Dr. Smith stated, "You can't just talk about the issues; you have to do something. Action takes the form of sending powerfully written letters or e-mails containing only a few important elements that explain what you want the 
legislators to accomplish." To help the participants understand advocacy messages, the presenters showed actual letters and e-mails that teachers had sent to their legislators, and modeled for them how to advocate in person.

The participants realized that they cannot ramble when advocating. Lisa stated, "When you advocate in person, you have to be very succinct and thoughtful." Jane echoed this point when she said, "I learned that short and to-the-point is the best way to talk about your position." Carol remembered the three-word phrase that she learned in the workshop. She said, "The three key ideas when advocating are brief, bold, and bye. Just say what you want, state it confidently, and then leave."

Next, the participants learned that teachers have credibility when discussing education-related issues. Carol explained, "You have to say that I'm a teacher, I have a classroom, and I know what the kids need. You then tell them what they need to know about the topic." Lisa elaborated:

We teachers have the experience, we have the knowledge, and we have the understanding of the research to advocate for what needs to happen in public education. If we're not standing up and saying here's what's not working to the legislators and those who are making the decisions, then no one else will. Having worked in education, I have seen superintendents make decisions that may not always be what's best for teachers and students. Unless teachers share their experience, better decisions will not be made.

Furthermore, the participants learned to control their emotions when communicating their message. Jane explained, "Teachers can have strong feelings about a bill and they want to express their feelings all the time. You want to be passionate, but you don't want your passion to take over and cloud your thoughts." Lisa recognized that emotions can negatively affect one's message. She noted, "It's not effective if you gush and put lots of feelings into it. Your emotions have to be tempered."

Finally, the participants learned various ways to deliver the message. Carol listed the ways when she said, "You can phone, e-mail, or post something on Facebook." Jane acknowledged that advocates can vary their intensity levels in each of these delivery methods. She added, "I learned that there are different levels of advocacy. You don't have to be as intense as some people. You can choose your level of involvement. Then, you can promote your position and fight for it."

\subsection{Legislative Aides}

During the third workshop the participants visited their state capitol. Dr. Smith explained, "I wanted the preservice teachers to understand that we all can go and visit our elected officials. It's not a closed door. Our legislators want to hear from us because we give them extra input on bills." To help the participants understand in-person advocacy, they observed Dr. Smith, an experienced advocate, speak to her state representative's aide about a proposed bill regarding social studies standards. Afterwards, Dr. Smith and the aide held a question-and-answer session to debrief the participants.

From the experience, the participants better understood the advocate's role in the process. Carol recounted:

It was really cool because we saw Dr. Smith actually do it. It was like we had a backstage access. We saw how it worked. It was an invaluable experience. It's one thing to talk about it, but it's another to actually go and do it. There is a big difference.

Jane added:

You need to be prepared, you need to know what you're talking about, you need to know the bill, and you need to understand your representative's stance. You're trying to convince the representative to vote in a certain way, so you are already supposed to know how they are probably going to vote. They just want to know why they should vote a certain way.

Realizing the importance of preparation, Carol asserted, "You need to be knowledgeable about what you want and why." Lisa was surprised about the roles of research and personal experience. She remarked, "They don't want a lot of research or information. They want to know what you think and why you think the way that you do."

The participants also learned about the role of the legislators and their aides. The participants noticed the energy level at the Capitol. Jane commented, "Walking through the Capitol, we could see all the commotion and the hustle and bustle. We witnessed our government in action. We saw that the legislative aides are very busy people, and tons of people stop by their offices." Lisa noted the seriousness of the work when she said, "The legislative process is like a business. It's like a complex machine. You have to know what you can and can't do. You can't try to outwork the system because the people in the office have limited time." 
Although the aides were busy, they welcomed the participants. Carol commented, "They are friendly, and they want to talk to you. They said that we didn't need to knock." She continued, "I was surprised at how accessible government people are. I had no idea that you could walk into the Capitol and into their offices. I forget that they work for the people; they're just like teachers." Jane discovered the aides' role in the process. She noted, "There's a team of people who work for the legislator. They can't speak for him, but they relay information to him."

\section{Discussion}

This descriptive case study examined what happened when three preservice teacher leaders learned about legislative advocacy through a professional organization. The findings show that they wanted to know about advocacy and that they possessed a basic understanding of the legislative process. The preservice teacher leaders also acquired the knowledge and skills needed to participate in legislative advocacy by participating in trainings and hands-on experiences sponsored by a professional organization in their teacher preparation program.

\subsection{Affirming Previous Research}

The findings affirm published scholarship in at least three ways. First, the results show that preservice teacher leaders can learn about legislative advocacy during their teacher preparation programs. These aspiring teacher leaders appreciated the presenters' in-depth knowledge and first-hand accounts of advocacy. Previous scholars have argued that exposure to experienced teacher leaders and their bold ideas is critical to the development of new teacher leaders (Holland, Eckert, \& Allen, 2014). Experienced teacher leaders can provide side-by-side mentoring and help the aspirants to identify ways they can lead (Shillingstad, McGlamery, Davis, \& Allen, 2015). The new teacher leaders in this study more clearly understood the advocacy process after observing the workshop presenter interact with her legislative aide at the State Capitol. The follow-up question-and-answer time with the aide further enriched the learning experience. Perhaps the pièce de résistance for the new teacher leaders was traveling to the State Capitol, experiencing the energy level of the people in the building, and interacting with the legislative aide. As Dunlap and Hansen-Thomas (2011) advised, "Participating in concrete and explicitly targeted experiences enhances the mentoring process and has an impact on beginning teachers' perceptions of self in leadership roles" (p. 23).

Second, the findings affirmed existing scholarship about what preservice teacher leaders bring to the advocacy experiences, specifically their reasons for attending and their levels of background knowledge. The workshops were planned because beginning teachers generally do not know how to share their insights and perspectives with a decision maker and do not possess a basic understanding of how decisions are made in state government. Previous scholars, such as Wade (2003), have been motivated to act for similar reasons. In her social studies methods course, Wade (2003) wanted her students to participate in advocacy-related events as a way to overcome their reluctance to advocate for children and learn how to bring about policy change. Similarly, Beacham and Shambaugh (2007) believed that if their students were more involved in community issues, then they would become more committed to serving the public as future educators. The participants described in this paper felt that they had some knowledge about education and wanted to share it. They viewed themselves the same way as Dever (2006) did, when he stated, "We are the experts when it comes to meeting the needs of children in our classrooms; it is our responsibility to be their advocates" (p. 391).

Third, the findings affirmed that professional organizations can provide educators at all levels with the knowledge, skills, and opportunities to advocate for the profession. The participants in the study were officers of a student chapter of an international honor society, the sponsor of the workshop series. Previous scholarship has shown that student professional organizations may be one way that teacher preparation programs can help preservice teachers to learn about and participate in advocacy-related activities. Lieberman (2014) recounts a conference in Washington, D.C., where she "learned how to speak to our representatives, how to package and present our desires, and how to follow up on our own at a later date. It was exciting and something I would have never done on my own" (p. 23). The event had such a positive effect on her that she now follows education policy and politics more closely. Other scholars such as Richards, Aros, and Ostrander (2015); Elpus (2007); and Radius, Galer-Unti, and Tappe (2009), extol the advocacy roles that professional organizations provide preservice and in-service teachers. Many professional organizations aim to inform their members of policy-related issues, train them in how to advocate, provide them with opportunities to advocate, and influence policy in the field.

\subsection{Adding to Previous Research}

The findings from the study add to previous research in two ways. First, previous research has examined preservice teachers learning to advocate for the profession; however, this study seems to provide more details about the process. 
Details include that the preservice teachers in the study did not know the specifics of the legislative process and advocacy. They did not know how to locate a proposed bill online, track it on the government's website, or determine when they could offer input to shape the bill. Furthermore, the preservice teachers did not know how to craft a message to deliver to legislators, specifically one that was succinct, direct, and non-emotional. In short, this study provides more details to the scholarly literature about what preservice teacher leaders know and can do in regard to advocacy. The findings indicate that the topic of advocacy is truly interesting and new to some preservice teachers.

Second, this study is unique because it chronicles preservice teachers who advocated in person. Although other studies have documented preservice teachers writing letters to legislators (Beacham \& Shambaugh, 2007; Dever, 2006; Massengale, Childers-McKee, \& Benavides, 2014; Wade, 2003) or explained briefly advocacy in person (Lieberman, 2014), none appear to have focused on advocating in person in depth. These preservice teachers enjoyed the energy they felt in the State Capitol, and they valued witnessing a more experienced advocate interact with a legislative aide. The experience appealed to their emotions and intellect; and, consequently, it gave them a clearer understanding of the advocacy process. These findings are new to the scholarly literature, but they are not unusual. Educators have been providing students with multi-sensory hands-on learning experiences for years.

\subsection{Limitations, Implications, and Areas for Further Research}

The study has some limitations. The findings cannot be generalized to a broader audience; however, they are significant because they document what happened to a small group of preservice teachers. Another limitation is the short amount of time that the participants were engaged in learning about advocacy. Three one-hour workshops may have minimal effect on the long-term development of these educators. Finally, the data collection instruments, specifically the interviews, captured these teachers' thoughts only after the three workshops concluded. A more thorough understanding of their learning might have come from having them each maintain a reflective journal during the entire process.

The study has implications for teacher educators. The discussion about education is prominent in public discourse today, and some decision makers are not seeking input from educators. As a way to remedy the situation and prepare teacher leaders to participate more in these discussions, advocacy should be included in the preparation of preservice teachers. Granted, the curriculum of a teacher preparation program is full, and teacher educators may be unwilling to omit any courses in lieu of advocacy. Despite the situation, the study offers a viable solution. Advocacy training and workshops could be offered through student professional organizations. The preservice teachers who are interested in advocacy could attend the workshops and then travel to their state capitol and practice using their new-found knowledge and skills. Many professional organizations at the state and national levels already engage in advocacy efforts, so the idea is a natural extension of their existing work. Also, the offering of advocacy training through student professional organizations in teacher preparation programs connects interested new teachers with experienced advocates who can mentor the novices and model ways to advocate for the profession.

Besides answering some key questions about preservice teacher leadership and advocacy, the study raised additional questions that merit future examination. For example, it would be interesting to examine preservice teachers who learn about advocacy and then advocate on their own to a legislative aide. Next, future studies could examine if there are differences in advocating at local, state, and national levels.

\section{Conclusion}

Lambert (2003) theorizes that teachers who are learning to lead move along a developmental continuum after first experiencing small, structured leadership opportunities. Over time, teachers become more knowledgeable and skilled at leading. Advocacy is one area where novice teacher leaders can learn to lead. If they are going to respond to the leadership call in the future as practicing teachers and engage in the discussions with decision makers to develop educational policy, then these aspiring teacher leaders need to learn how to lead and advocate for the profession during their preparation programs. Not all preservice teacher leaders will respond to this call or express an interest in advocacy, but a small group of the most interested and intrinsically motivated ones will. Therefore, student professional organizations may be one way that the novice teacher leaders can step forward, learn about teacher leadership and advocacy, and practice what they have learned. When preservice teachers learn about advocacy, they will be equipped to respond to the call and participate more actively in the process of making policy decisions as a way to fulfill their professional and ethical responsibilities. 


\section{Acknowledgements}

The author would like to thank Kathleen Magor for her insightful feedback on this manuscript.

\section{References}

Beacham, C. V., \& Shambaugh, N. (2007). Advocacy as a problem-based learning (PBL) teaching strategy. International Journal of Teaching and Learning in Higher Education, 19(3), 315-324.

Bogdan, R. C., \& Biklen, S. K. (2007). Qualitative research for education: An introduction to theory and methods (5th ed.). Boston, MA: Pearson/Allyn and Bacon.

Bond, N. (2011). Preparing preservice teachers to become teacher leaders. The Educational Forum, 75(4), $280-297$. http://dx.doi.org/10.1080/00131725.2011.602578

Coggins, C., \& McGovern, K. (2014). Five goals for teacher leadership. Phi Delta Kappan, 95(7), 15-21. http://dx.doi.org/10.1177/003172171409500704

Cohen, L. (2008). Educating the world: Essential schools as agents of change and influence. Horace, 24(3), 1-3.

Corbin, J., \& Strauss, A. (2008). Basics of qualitative research: Techniques and procedures for developing grounded theory (3rd ed.). Los Angeles, CA: Sage Publications.

Crippen, C. (2010). Serve, teach, and lead: It's all about relationships. InSight: A Journal of Scholarly Teaching, 5, 27-36.

Dever, M. T. (2006). Advocating for young children: A preservice teacher education project. Journal of Early Childhood Teacher Education, 27(4), 391-399. http://dx.doi.org/10.1080/10901020600996299

Diana, T. J. (2011). Becoming a teacher leader through action research. Kappa Delta Pi Record, 47(4), 170-173. http://dx.doi.org/10.1080/00228958.2011.10516586

Dunlap, K., \& Hansen-Thomas, H. (2011). Taking the reins: Preservice teachers practicing leadership. Educational Horizons, 90(2), 21-24.

Eckert, J., Ulmer, J., Khachatryan, E., \& Ledesma, P. (2015). Career pathways of teacher leaders in the United States: Adding and path-finding new professional roles. Professional Development in Education, 1-23. http://dx.doi.org/10.1080/19415257.2015.1084644

Elpus, K. (2007). Improving music education advocacy. Arts Education Policy Review, 108(3), 13-18.

Flom, J. (2010). Emerging trends: Teachers as advocates. Cooperative Catalyst. Retrieved from http:/coopcatalyst.wordpress.com/2010/06/11/emerging-trend-teachers-as-advocates/

Galer-Unti, R. A., Tappe, M. K., \& Lachenmayr, S. (2004). Advocacy 101: Getting started in health education advocacy. Health Promotion Practice, 5(3), 280-288.

Greenleaf, R. K. (1977). Servant leadership: A journey into the nature of legitimate power and greatness. New York, NY: Paulist Press.

Hammett, M. (2006). Promoting student advocacy in Tennessee. ASHA Leader, 11(8), 18.

Hess, F. M. (2015). Busting out of the teacher cage. Phi Delta Kappan, 96(7), 58-63. http://dx.doi.org/10.1177/0031721715579042

Holland, J. M., Eckert, J., \& Allen, M. M. (2014). From preservice to teacher leadership: Meeting the future in educator preparation. Action in Teacher Education, 36(5-6), 433-445. http://dx.doi.org/10.1080/01626620.2014.977738

Kajitani, A. (2015). How do you know whether you're a teacher leader? Kappa Delta Pi Record, 51(3), 121-125. http://dx.doi.org/10.1080/00228958.2015.1056663

Lambert, L. (2003). Leadership capacity for lasting school improvement. Alexandria, VA: Association for Supervision and Curriculum Development.

Lieberman, D. S. (2014). Connect, risk, ask, share, lead! Phi Delta Kappan, 95(7), $22-23$. http://dx.doi.org/10.1177/003172171409500705

Massengale, K., Childers-McKee, C., \& Benavides, A. (2014). Exploration of undergraduate preservice teachers' experiences learning advocacy: A mixed-methods study. Journal of Scholarship of Teaching and Learning, 
14(3), 75-92.

McMillan, J. H. (2016). Fundamentals of educational research (7th ed.). Boston, MA: Pearson.

Palmer, P. J. (2008). On the edge: Have the courage to lead with soul. Journal of Staff Development, 29(2), 12-16.

Pucella, T. J. (2014). Not too young to lead. Clearing House: A Journal of Educational Strategies, Issues and Ideas, 87(1), 15-20. http://dx.doi.org/10.1080/00098655.2013.818524

Radius, S. M., Galer-Unti, R. A., \& Tappe, M. K. (2009). Educating for advocacy: Recommendations for professional preparation and development based on a needs and capacity assessment of health education faculty. Health Promotion Practice, 10(1), 83-91. http://dx.doi.org.libproxy.txstate.edu/10.1177/1524839907306407

Richards, K. A., Aros, E., \& Ostrander, A. (2015). Integrating advocacy into teacher education programming. Strategies, 28(6), 42-44. http://dx.doi.org/10.1080/08924562.2015.1088345

Robinson, A., \& Stark, D. R. (2005). Advocates in action: Making a difference for young children. Washington, DC: National Association for the Education of Young Children.

Shillingstad, S. L., McGlamery, S., Davis, B., \& Gilles, C. (2015). Navigating the roles of leadership: Mentors' perspectives on teacher leadership. Delta Kappa Gamma Bulletin, 81(2), 12-20.

Silva, D. Y., Gimbert, B., \& Nolan, J. (2000). Sliding the doors: Locking and unlocking possibilities for teacher leadership. Teachers College Record, 102, 779-804.

Snyder, J. (2015). Teacher leadership and teacher preparation: A personal narrative. Educational Forum, 79(1), 5-11. http://dx.doi.org/10.1080/00131725.2015.972801

Teach Plus (2015). Retrieved from http://www.teachplus.org

$\begin{array}{llllll}\text { Teacher } & \text { Leadership } & \text { Model } & \text { Standards. } & \text { (2011). } & \text { Retrieved from }\end{array}$ www.teachingquality.org/sites/default/files/teacher_leader_model_standards.pdf

Wade, R. (2003). Teaching preservice social studies teachers to be advocates for social change. Social Studies, 94(3), 129-133.

Yaffe, D. (2014). Leadership lifts teachers. District Administration, 50(12), 57-60.

Yin, R. K. (2014). Case study research: Design and methods (5th ed.). Thousand Oaks, CA: Sage.

York-Barr, J., \& Duke, K. (2004). What do we know about teacher leadership? Findings from two decades of scholarship. Review of Educational Research, 74(3), 255-316. 